\section{STUDIES IN AMERICAN FICTION}

Department of English Northeastern University

Editor
Mary Loeffelholz
Editorial Assistant
Aaron Pikcilingis

Editorial Board.
Northeastern University

Samuel J. Bernstein, Laura Morgan Green, Wayne Franklin, Cassandra Jackson, M. X. Lesser, Guy L. Rotella, Bonnie TuSmith

\section{Advisory Editors}

Roger Asselineau (University of Paris-Sorbonne), Nina Baym (University of Illinois), Millicent Bell (Boston University), Lawrence Buell (Harvard University), Clarence Glasrud (Moorhead State University), James J. Martine (Saint Bonaventure University), James E. Miller, Jr. (University of Chicago), George Monteiro (Brown University), Timothy Morris (University of Texas at Arlington), Donald Pizer (Tulane University), Joel Porte (Cornell University), Shirley Samuels (Comell University), Ben Siegel (Califomia State University) Carol J. Singley (Rutgers University), Linda Wagner-Martin (University of North Carolina), Sandra A. Zagarell (Oberlin College)

Studies in American Fiction is a journal of articles and reviews on the prose fiction of the United States. Manuscripts should follow our established style in all matters of quotation and documentation. Published twice each year, in May and December, by the Department of English, Northeastern University, Studies in American Fiction is indexed in the MLA Bibliography and the American Humanities Index.

Annual subscriptions are $\$ 9.00$ for individuals, $\$ 12.00$ for individuals outside the United States, and $\$ 15.00$ for institutions, $\$ 17.00$ for foreign institutions Address all correspondence regarding subscriptions and manuscript submissions to

$$
\begin{aligned}
& \text { Mary Loeffelholz, Editor } \\
& \text { Studies in American Fiction } \\
& \text { Department of English } \\
& \text { Northeastern University } \\
& 360 \text { Huntington Avenue } \\
& \text { Boston, Mass. 02115-5000 } \\
& \text { Phone: } 617-373 \text {-3687 }
\end{aligned}
$$

\section{STUDIES IN AMERICAN FICTION}

Department of English Northeastem University

Volume 30

Spring 2002

Number 1

\section{Contents}

\section{Psyche, Psychoanalysis, and American Fictions}

Beverly A. Hume, Managing Madness in Gilman's "The Yellow Wall-Paper"

Joseph Church, Romantic Flight in Jewett's "White Heron"

Jeffrey Andrew Weinstock, In Possession of the Letter: Kate Chopin's "Her Letters"

Chip Rhodes, Ambivalence on the Left: Budd Schulberg's What Makes Sammy Run?

\section{Class Fictions}

Phillip Schweighauser, "You Must Make Less Noise in Here; Mister Schouler": Acoustic Profiling in American Realism

Amy Blair, Rewriting Heroines: Ruth Todd's "Florence Grey," Society Pages, and the Rhetorics of Success 


\section{"YOU MUST MAKE LESS NOISE IN HERE, MISTER SCHOULER": \\ ACOUSTTC PROFULING IN AMERICAN REALISM}

Philipp Schweighauser

University of Basel, Switzerland

Narrative's broad tange of scholarship includes the novel, narrative poetry, nonfiction narrative, film, and narrative as used in the visual and performing arts. The journal is especially interested in essays combining theoretical investigation and practical criticism.

Recent and Forthcoming Contributions Include:

Uri Margolin

"Naming and Believing: Practices of the Proper Name in Narrative Fiction"

Dan Sheri

"Defense and Challenge; Reflections on the Relation between Story and Discourse"

Nina K. Leacock

"Character, Silence, and the Novel: Walter Benjamin on Goethe's Elective Affinities"

Genie Babb

"Where the Bodies Are Buried: Cartesian Dispositions in Narrative Theories of Character"

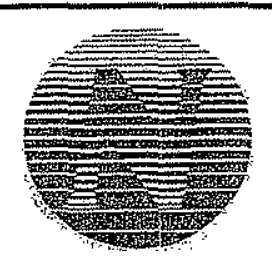

Narrative, sponsored by the Sociery for the Study of Narrative Literanure, is published three times a year by Ohio State University Press. 2003 Subscriptions: $\$ 35$ individual (includes membership in the Society for the Study of Narrative Literature), \$47 institution.

The Ohio State University Press, 1070 Carmack Rd., Columbus, OH 43210 www.ohiostatepress.org

When Walt Whitman proudly named America a "nation of nations" and celebrated "the perpetual coming of immigrants" in his 1855 preface to Leaves of Grass, ${ }^{1}$ he referred both to the settlement of America by European immigrants and to a process that was only just beginning when he published the first edition of his monumental book of poetry. The historian Philip Jenkins describes this process as follows:

American industrial expansion was made possible by the ready availability of cheap labour in the form of the huge numbers of migrants entering the country from the 1860 s onwards. From the 1880 s the scale of migration constituted the largest population movement in recorded history. Between 1881 and 1920 there were over 23 million immigrants: 1907 was the peak year, with 1.2 million newcomers .... This migration had a radical effect on the ethnic composition of the United States. Before 1880 the vast majority of immigrants came from the British Isies or Northem Europe, chiefly Germany; but after that point the emphasis shifted decisively to the peoples of southern and eastem Europe, including Ytalians, Poles, Hungarians and all the nationalities of the Austrian-Hungarian Empire. In 1870 New York City had 80,000 Jews; by 1915 there were 1.5 million. By

1930 perhaps six million Americans were of Italian stock. ${ }^{2}$

Realist and later writers, confronted with a dramatic increase in immigration, were often far less enthusiastic than Whitman about the growing ethnic diversity of the United States. In their texts, the new immigrant voices came under careful and often critical scrutiny.

A common representational strategy was to emphasize the obscurity of foreign-sounding speech. Howells participates in this when, in A Hazard of New Fortunes (1890), he has Basil March comment on "the jargon" of the Neapolitans" "unintelligible dialect,"3 and so does Henry Adams in The Education (1907) when he evokes the olfactory and linguistic profile of "a furtive Yacoob or Ysaac still reeking of the Ghetto, snarling a weird Yiddish to the officers of the customs." $\mathrm{Im}$ migrant voices, Howells and Adams seem to imply, are often nothing 
but unintelligible noise. Howells's representation of the German-American socialist Lindau's speech follows a similar pattern as its exaggerated mispronunciations undermine the seriousness of his concerns: "What is Amerigan? Dere iss no Ameriga anymore! You start here free and brafe, and you glaim for efery man de right to life, liperty, and de bursuit of happiness. And where haf you endedt?" (276). Daniel Borus links the portrayal of Lindan's speech to the processes of exclusion enacted by realist texts: "There are limits to the realist approach. At times realists seemed incapable of penetrating fully into the lives of their subjects. Much as Howells pointed up the foreignness of Lindau's speech through spellings that overemphasized mispronunciations ("lawss"), realists marked out some of 'the people' as ioferior or as distant." Lindau's heavy accent serves to reinforce the otherness and strangeness of his socialist ideas.

In Norris's McTeague (1899), similar processes of exclusion are at work. Mr. Sieppe's ridiculousily exaggerated German accent and garbled syntax combine with his militaristic posturing to produce the caricature of a German-American who functions as the novel's primary laughingstock:

"Owgooste!" he shouted to the little boy with the black greyhound, "you will der hound und der basket number three carry. Der tervins," he added, calling to the two snallest boys, who were dressed exactly alike, "will releef one unudder mit der camp-stuhl and basket number four. Dat is coraprehend, hay? When we make der start, you childern will in der advance march. Dat is your orders."

More interesting still is the case of Marcus Schouler, Mr. Sieppe's nephew. While not afflicted with the linguistic shortcomings of his uncle, Marcus's speech is repeatedly designated as noise. The reader meets Marcus as he accompanies McTeague to a saloon in the novel's first chapter:

Marcus had picked up a few half-truths of political economy-it was impossible to say where-and as soon as they had settled themselves to their beer in Frenna's back room he took up the theme of the labor question. He discussed it at the top of his voice, vociferating, shaking his fists, exciting himself with his own noise. (13)

Through the figure of Marcus Schouler, Norris makes explicit what is only implied in Howells's portrayal of Lindau. Like Lindau, Schouler is a German-American socialist whose diatribes against social inequalities are compromised by his linguistic profile. While Norris"s Schouler-who rails against "Chinese cigar-makers" (121) in decidedly racist terms (" $\mathrm{Ah}$, the rat-eaters! $\mathrm{Ah}$, the white-livered curs") and at one point attempts to stab an unarmed McTeague-is obviously presented as a far more negative figure than Howells's Lindan, the two authors' treatment of political dissenters shows striking parallels. The saloon owner Frenna's admonition to Schouler could serve as a motto for my discussion of the constrained roles played by socialist figures in both novels: "You must make less noise in here, Mister Schouler" (140).

With the Polish-American Jew Zerkow, yet another immigrant becomes the object of acoustic profiling in McTeague. The passages on Zerkow, a man whose "dominant passion" is "inordinate, insatiable greed" (43), are so clearly anti-Semitic that one begins to wonder whether Marcus Schouler's attack on Chinese cigar-makers was actually intended to reflect negatively on him. Norris's anti-Semitism culminates in his depiction of Zerkow's murder of Maria. The harness-maker Heise's description of Maria's body contains an unequivocal reference to shechitah, the kosher way of slaughtering animals by slitting their throat with a very shape knife: "He's done for her sure this trip. Cut her throat. Lord, how she has bled! Did you ever see so much-that's murder-that's cold-blooded murder" (318). Prior to this climactic event, Zerkow's depravity is reflected in and reinforced by the quality of his voice:

"Who is it? Who is it?" cried the rag-picker from within, in his hoarse voice, that was half whisper, starting nervously, and sweeping a handful of silver into his drawer. (125)

"Now, then, Maria," said Zerkow, his cracked, strained voice just rising above a whisper, hitching his chair closer to the table, "now, then, my girl, let's have it all over again. Tell us about the gold platethe service. Begin with, "There were over a hundred pieces and every one of them gold." (239)

"You fool!" he wheezed, trying to raise his broken voice to a shout. "You fool! Don't you dare try an' cheat $m e$, or I'll do for you. You know about the gold plate, and you know where it is." Suddenly be pitched his voice at the prolonged rasping shout with which he made his street cry. He rose to his feet, his long, prehensile fingers curled into fists. He was menacing, terrible in his rage. (242) 
In his portrayal of Zerkow, Norris uses a strategy well-known from fairy tales, in which the motal depravity of villains is always reflected in their external appearance: witches are not only wicked but also have a croaking voice, a warty nose, a hunchback. In their conflation of external appearance and internal essence, fairy tales participate in the economy of mythical thought, for which, according to Exnst Cassirer, "the attribute is not one defining aspect of the thing; rather, it expresses and contains within it the whole of the thing." Norris's depiction of Zerkow repeats that pattern: "He was a dry, shrivelled old man of sixty odd. He had the thin, eager, cat-like lips of the covetous; eyes that had grown keen as those of a lynx from long searching amidst muck and debris; and claw-like, prehensile fingers" (42-43). On the one hand, Zerkow's grating voice merely adds to his hideous appearance and serves to reinforce his wickedness. But once we recognize the similarities in the rendition of Zerkow's, Schouler's and Lindau's speech and keep in mind that they are all immigrants, we discover an additional mechanism at work.

These literary figures take their place in a long history of linguistic struggles that involve disparaging the language of others as noise. As Bruce Smith points out, the Irish tongue of their colonial subjects was to many English observers of the early modern era but "one step removed from noise."; a sixteenth-century commentator even went as far as arguing that "the Irish language was forged out of the debris of $\mathrm{Ba}$ bel." $\mathrm{A}$ faint echo of such attitudes can still be heard in the strike scene of Dreiser's Sister Carrie (1900) during which an "old Irishwoman" yells at the police officers for beating her son while one of the screaming strikers is singled out as "a young Irishiman." The narrator's description of the ensuing "babel of voices" (427) owes as much to the uproar of the riotous strike as to the presence of immigrant Irish voices. A similar rhetoric was used by European colonizers of Native American soil, who evoked the corruptness of Indian languages to justify the displacement and eventual destruction of native lives:

Prompted by the biblical account of the Tower of Babel, Europeans were predisposed to hear in Native American languages evidence of confusion, dispersal, and degeneration. Robert Johnson, arguing the case for further colonization in his pamphlet The New Life of Virginea (1612), cites the barbarity of the Algonkian language as evidence of its speakers' depravity - and of their aptness for being pulled up and discarded like so many weeds. ${ }^{10}$
While the portrayal of Lindau, Schouler, and Zerkow does not proceed along identical lines, their exclusion from the fictional communities-a the center of McTeague and A Hazard of New Fortunes at least partly repeats the pattern identified by Smith. These novels enact a symbolic form of violence, as their immigrant characters' speech along with that of the ethric communities they represent are identified as noise.

In the work of French sociologist Pierre Bourdieu, symbolic violence designates the exercise of the power to represent the legitimate social world, of the power to impose one's vision of the world, one's meanings, on others. The power to exert symbolic violence is the "power which manages to impose meanings and to impose them as legitimate by concealing the power relations which are the basis of its force." 11 In Bourdieu's scheme, educational institutions are among the main perpetrators of symbolic violence. Their "pedagogic actions" inculcate the values and systems of meaning of the dominant class, thereby reproducing in covert form the existing relations of power. ${ }^{12}$ As "the imposition of a cultural arbitrary by an arbitrary power," 13 symbolic violence relies on a hierarchy of values, practices and ways of reading the world that are misrecognized as legitimate by both its practitioners and recipients. ${ }^{14}$ In a series of essays originally published in the late 1970s and early 1980s and collected in English translation in Language and Symbolic Power, Bourdieu applies his findings to the study of language. ${ }^{15}$ In line with his stated intention "to extend economic calculation to all the goods, material and symbolic, without distinction, that present themselves as rare and worthy of being sought after in a particulat social formation," "16 Bourdieu frames his argument in economic terms:

Linguistic exchange ... is also an economic exchange which is established within a particular symbolic relation of power between a producer, endowed with a certain linguistic capital, and a consumer (or a market), and which is capable of producing a certain material or symbolic profit. In other words, utterances are not only (save in exceptional circumstances) sigus to be understood and deciphered; they are also signs of wealth, intended to be evaluated and appreciated, and signs of authority, intended to be believed and obeyed. ${ }^{17}$

Language in Bourdieu becomes linguistic capital. As such, it participates in the larger economies of cultural capital (various forms of legitimate knowledge) and symbolic capital (prestige, honor, social recognition) and thus takes its place among other kinds of capital, including social capital (valued social relations) and economic capital. ${ }^{18}$ 
What counts on the linguistic marketplace is less the content than the style of one's speech. Dreiser's Hurstwood is keenly aware of this when, hobnobbing with the socially superior, he engages in the most meaningless conversations: "Then began one of those pointless social conversations so common in American resorts where the would-be gilded attempt to rub off gilt, from those who have it in abundance" (265-66). As Hurstwood knows, such linguistic exchanges are only "pointless" with regard to their propositional meaning. At the level of social interaction, they constitute important investments of social and symbolic capital that in the long run may well yield a profit measurable in strictly economic terms. As Dreiser points out, much of the linguistic knowledge required to secure symbolic profits on such occasions is formulaic in nature: "Did you ever hear the story of,' and 'That reminds me,' were the most repeated phrases" (266). The symbolic value of such formulaic mastery becomes particularly evident if we compare Hurstwood to a character who clearly lacks this sort of pragmatic linguistic knowledge. Determined to procure tickets for a spectacle he intends to attend with Trina and his prospective parents-in-law, Norris's McTeague musters all his courage, approaches the ticket booth and "deliver[s] himself of the formula he had been reciting for the last dozen hours":

"I want four seats for Monday night in the fourth row from the front, and on the right hand side."

"Right hand as you face the house or as you face the stage?" McTeague was dumfounded.

"I want to be on the right-hand side," he insisted, stolidly; adding, "in order to be away from the drums."

"Well, the drums are on the right of the orchestra as you face the stage," shouted the other impatiently; "you want to the left, then, as you face the house."

"I want to be on the right-hand side," persisted the dentist.

Without a word the seller threw out four tickets with a magnifi. cent, supercilious gesture. "There's four seats on the right-hand side, then, and you'te right up against the drums."

"But I don't want to be near the drums," protested McTeague, beginning to perspire. (94)

The exchange, during which McTeague becomes increasingly confused and the seller begins to laugh at him, continues for another page. Due to his inexperience and inability to produce linguistic expressions appropriate to the situation, McTeague loses face. In Bourdieu's terms,
McTeague incurs heavy symbolic losses while the seller secures symbolic profits as he demonstrates his superior knowledge at McTeague's expense. McTeague instinctively recognizes the (symbolic) violence that is being done to him and threatens to retaliate with the physical violence he knows all too well: "you-you can't make small of me. I'll thump you in the head, you little-you little-little-little pup" (95).

As is already indicated by these short analyses of two very different social situations, a reading informed by Bourdieu's theories allows for a more subtle investigation into fictionalized social interactions than the deterministic interpretations repeatedly offered by naturalist texts. Central to Bourdieu's project is his desire to transcend the classical opposition between objectivism (whose analyses tend to overemphasize the role played by social structures and rules in the construction of social reality) and subjectivism (whose analyses often exaggerate the importance of individual agency and conscious, rational decision-making) in the social sciences. ${ }^{19}$ Human actors are obviously neither mere products of society nor agents free to do whatever they desire. Bourdieu's concept of the "habitus" allows him to steer a middle course between the two extremes:

The structures constitutive of a particular type of environment (e.g. the material conditions of existence characteristic of a class condition) produce habitus, systems of durable, transposable dispositions, structured structures predisposed to function as structuring structures, that is, as principles of the generation and structuring of practices and representations which can be objectively "regulated" and "regular" without in any way being the product of obedience to rules, objectively adapted to their goals without presupposing a conscious aiming at ends or an express mastery of the operations necessary to attain therm and, being all this, collectively orchestrated without being the product of the orchestrating action of a conductor. ${ }^{20}$

The habitus does not strictly determine the practices of social actors. Rather, it "disposes actors to do certain things, it provides a basis for the generation of practices. "21 Nevertheless, the generative force of the habitus is strong enough to ensure that the practices of social actors who have undergone a similar process of inculcation tend to exhibit a high degree of similarity. Members of a given class therefore share a class habitus that manifests itself in similarities between the most dim verse practices, ranging from similar aesthetic preferences, occupational choices and consumption patterns to similar ways of eating, 
dressing, walking and talking, all the practices, in other words, that make up a given life-style. ${ }^{22}$ In the fictional world of Dreiser's Sister Carrie, it is its manifestations of a class habitus more distinguished than their own that make Rector's-where "one could encounter politicians, brokers, actors, some rich young 'rounders' of the town, all eating and drinking amid a buzz of popular, commonplace conversation" (42)-such a desirable place to both Drouet and Hurstwood.

In Bourdieu's model, linguistic expressions are generated on the basis of the dispositions of the linguistic habitus. These dispositions "imply a certain propensity to speak and to say determinate things (the expressive intent) and a certain capacity to speak, which involves both the linguistic capacity to generate an infinite number of grammatically correct discourses, and the social capacity to use this competence adequately in a determinate situation." 23 The fact that the "social capacity" Bourdieu refers to is distributed unequally allows speakers with a favorable linguistic habitus to secure symbolic profits on the linguistic market, for example by being able to address an audience in a formal or official setting. ${ }^{24}$ McTeague is shown to lack this capacity when he is forced to give a speech on the occasion of his engagement to Trina: "I don' know what to say-I-I-I ain't never made a speech before; I-I ain't never made a speech before. But I'm glad Trina's won the prize-" $(120)$. At the other end of the spectrum, we find the linguistic habitus of the mill-owner Kirby in Davis's "Life in the Iron Mills," whose voice is "like music,--low, even, with chording cadences," or that of the Christian reformer whose speech in a Gothic church-which was "built to meet the requirements and sympathies of a far other class than Wolfe"s" - is "clear, feeling, full, strong," and sounds in Wolfe's ears "a very pleasant song in an unknown tongue."25

The logic of symbolic loss and profit permeates all social practices, but only some actors, those with the appropriate habitus-Kirby rather than Wolfe-are likely to profit on the market of symbolic goods. A social actor's habitus, acquired during a long process of socialization, is therefore a form of "internalized capital."26 "Internalization" can be taken literally not only because the habitus is a form of internalized social structure but also because it manifests itself in what Bourdieu calls bodily (or corporeal or body) hexis: "Body hexis speaks directly to the motor function, in the form of a pattern of postures that is both individual and systematic, because linked to a whole system of techniques involving the body and tools, and charged with a host of social meanings and values."27 For Bourdieu, symbolic relations of power are manifested in the minutiae of corporeal behavior, in "a way of talking, a tilt of the head, facial expressions, ways of sitting and of using implements, always associated with a tone of voice, a style of speech, and (how could it be otherwise?) a certain subjective experience." Bodily hexis thus both signals and creates distinction, it is "political mythology realized, em-bodied, turned into a permanent disposition, a durable manner of standing, speaking, and thereby of feeling and thinking."29

Refracted through Bourdieu's twin concepts of habitus and hexis, language becomes but one form of corporeal expressiveness to which meanings and values are attached in social interaction. This makes immediate sense if we return for a moment to the portrayal of immigrant speech in Howells and Norris. Only two characters' speech forms, Lindau's and Mr. Sieppe's, are identified as foreign in strictly linguistic terms. In the cases of Schouler and Zerkow it is prosodic and paralinguistic features, an excessive loudness and a hoarse whispering quality respectively, that mark their linguistic productions as deviant. The distinctive earmarks of Zerkow's speech are located somewhere on a continuum between the phonemes of language, on one end of the spectrum, and on the other, nonverbal sounds produced by the human voice (wheezing, sobbing, clearing one's throat). In all four cases, the effect remains the same: Norris and Howells furnish their immigrant characters with a bodily hexis whose vocal manifestations are endowed with very little symbolic capital and thereby relegate not only them but also the political views and ethnicities they represent to the margins of their fictional worlds. Rather than contributing to a critique of symbolic violence, these late nineteenth-century texts enact that violence in their processes of exclusion.

In realist and naturalist fiction, this pattern is confined to neither immigrant characters nor to the sounds of the human voice. Like human beings, fictional characters are not merely passive receivers of acoustic phenomena but active participatants in the making of the soundscapes they live in. ${ }^{30}$ In Maggie's entertainment halls, for instance, the boisterous crowd is responsible for half the spectacle. Characters in novels snore, sigh, snarl and scream; they grunt, gabble, gossip and grumble; they clamor, cry, cough and curse. At a more basic level, human bodies, fictional or not, continually produce noises whether they walk, stand still, sleep, get up, or sit down. If you try to shut your ears the way you shut your eyes, you will still hear yourself breathing. If you hold your breath, you will still hear the blood circulating in your 
veins. Only death truly silences human bodies. If observed, the noises people make will be subject to the value judgments of observers. Democratic presidential candidate Al Gore learned this lesson the hard way when he was widely accused of bad manners for sighing audibly to indicate his disapproval with several statements made by his Republican opponent George W. Bush during the televised pre-election debates in 2000. Realist and later authors were very much aware of such mechanisms and constructed acoustic profiles for their characters to indicate various character traits that serve both to position characters on the social scale and to direct readers' judgment of thern.

These indicators are often singular and subtle in nature. For instance, once Dreiser has Carrie confess her love to Hurstwood and perceive that "worthy" as "a drag in the direction of honor" (131), Drouet's lack of refinement is thrown into sharp relief against Hurstwood's elegance: “DDrouet] plunged his face in a basin of water and puffed and blew as he rubbed his neck and ears with his hands, the while Carrie gazed upon him with mingled thoughts of recollection and present judgment" (135). Readers will understand immediately that delicate Carrie does not approve of what she sees and hears, and they will not be surprised when they learn on the following page that Carrie feels "for the first time . . . as if she must move away from him" (136). At this point in the narrative, Drouet no longer possesses either the economic or the symbolic capital Carrie is looking for. The episode has two related narrative functions: it prepares the reader for Carrie's growing estrangement from Drouet and at the same time foreshadows Drouet's eventual disappearance from the narrative's main concerns. It therefore drives a wedge not only between Drouet and Carrie, but also between Drouet and the reader, whose emotional involvement with this character is gradually displaced to other characters.

While acoustic profiling is confined to isolated episodes in Dreiser, Frank Norris's McTeague is a different case altogether. At the center of events throughout the narrative, McTeague is furnished by Norris with a consistent acoustic profile, or audiograph. I define an audiograph as a characterization technique that endows fictional bodies with a set of distinctive acoustic properties designed to position characters with regard to the ensemble of social facts and practices that constitute the fictional world they inhabit. These acoustic properties may range from a character's accent, dialect or intonation patterns to the sounds produced by his laughter, snoring, or the impact of his footsteps. The positioning accomplished via audiographs may involve value judgments on the part of other characters, narrators and implied authors as well as implied and empirical readers. Following Bourdieu, I trace the often striking unity of both acoustic practices and the value judgments that are attached to thern to the "synthetic unity" of the habitus." While audiographs may be used as part of the narrative technique of telling (for instance when a narrator censures a character's snoring), their principal mode of operation is clearly showing.

Besides its sheer massiveness and strength, one of the more remarkable characteristics of McTeague's body is the amount of noise it produces. When he walks, the air vibrates with the sound of the "heavy, elephantine tread of [his] huge feet" (185) or the noise of "his great feet dragging and grinding on the floor" (374). When he forces his breath through his nose, he emits "a fearful snorting noise" (136). McTeague does not laugh the way other characters do; he "bellow [s] with laughter" (136) or "explode[s] in a roar of laughter" (99). While Trina chuckles "demurely, her lips closed tight, her little chin thrust out, her small pale nose, with its adorable little freckles, wrinkling," McTeague "roar[s] with all the force of his lungs, his enormous mouth distended, striking sledge-hammer blows upon his knees with his clenched fist" (75). Even bis singing in the morning is "a bellowing roar, enough to make the window sashes rattle" (62). When he is angry or excited, McTeague's "enormous jaws shut together with a sharp click" (59) and his teeth begin to "gr[i]nd themselves together with a little rasping sound" (31). When he is furious, his voice breaks forth into a deafening scream. This is his initial reaction to Marcus biting him during a wrestling match:

Then followed a terrible scene. The brute that in McTeague lay so close to the surface leaped instantly to life, monstrous, not to be resisted. He sprang to his feet with a shrill and meaningless clamor, totally unlike the ordinary bass of his speaking tones. It was the hideous yelling of a hurt beast, the squealing of a wounded elephant. He framed no words; in the rush of high-pitched sound that issued from his wide-open mouth there was nothing articulate. ... His only idea was to batter the life out of the man before him, to crush and annihilate him upon the instant. (234)

The animal in him, itself described as "shouting and clamoring" (30) not far below the surface, is released in an outburst of violence. Two representational strategies intersect here as the slippage from voice to noise ("meaningless clamor," "nothing articulate") -which we have 
already encountered in the portrayal of Lindau, Sieppe, Schouler, and Zerkow-combines with the reduction of the human voice to the animal squeal, positioning McTeague beyond the limits of human intelligibility and coguition. McTeague's audiograph, which includes his more narrowly linguistic deficiencies (stammering when excited, limited range of vocabulary, lower-class sociolect), thus contributes significantly to the process of "casting out the outcast," which June Howard has identified as a central concern of naturalist narratives. ${ }^{32}$

In A Hazard of New Fortunes, Howells uses audiographs to indicate the degree to which characters belong to certain social spheres. What the members of the Dryfoos family fail to notice despite its obviousness to other characters in the novel is that their economic capital does not guarantee them right of access to the social circles that the Marches, who possess far less economic capital than they do, move in with perfect ease. The Dryfoos girls misunderstand the fundamental processes at work when they attribute their difficuities in gaining access to these circles to "an accident which would be repaired as soon as the fact of their father's wealth [got] around" (224). What the Dryfooses lack, and what makes their eventual departure from New York almost a narrative necessity, are other forms of capital. Dryfoos used to be a farmer in Moffitt, Indiana until he made a fortune selling the greatest part of his land to the Standard Oil Company and investing the money in land speculation. Moved to New York to "spend his money and get his daughters into the old Knickerbocker society" (78), as Fulkerson puts it, Dryfoos is confronted with the fact that his family's background in farming provided little of the symbolic, social and cultural capital (refined speech, taste in music, valued social relations, educational qualifications) sought after in cultivated New York circles. ${ }^{33}$ Accordingly, the Dryfoos girls are described as "ignorant and unbred" (223) by the narrator. Fulkerson's "invention" (143) of Mrs. Mandel as the Dryfoos household's governess presents his failed attempt to remedy this situation. In the eyes of New York society, the Dryfooses remain nouveaux riches, upstarts unable to shake off their boorish behavior.

The Dryfooses' lack of appropriate forms of capital is manifested in their shared bodily hexis, which signals and adds to their inability to secure profits of distinction. Particularly its acoustic dimension marks them as unfit for inclusion in the social sphere of the Horns and the Vances. First of all, there is their Midland dialect, which immediately identifies them as "country folk." ${ }^{34}$ Elizabeth Dryfoos retains its linguistic features best: "You hain't never heared o' the Dunkards, I reckon
Some folks calls 'em the Beardy Men, because they don't never

shave; and they wash feet like they do in the Testament" (137). But her daughters' talk also contributes significantly to their perception by New. Yorkers as, in the words of Isabel March, "common, stupid, inarticu. late country person[s]" (194-95). Mela's description of buming gas wells to Margaret Vance provides a case in point: "Yes, and when you see the surface gas burnun' down in the woods, like it used to by our spring house-so still, and never spreadun' any, just like a bed of some kind of wild flowers when you ketch sight of it a piece off' (222). Then there is Mela's "hoarse laughter" and "talk full of topical and syntactical freedom," which puts off a "motherly matron" who "perceived their isolation and made overtures to them" (271). Mela's "Iarge, coarse laugh" (220) has nothing of the fearful quality of her father's, who laughs. "showing his lower teeth in a way that was at once simple and fierce" (186), but when she lets it out "in deep gurgles" (235) at Mrs. Horn's musicale, it marks her lack of tefinement equally sharply. In the safety of their home, "Mela's hoarse babble" competes with "Christine's high-pitched, thin, sharp forays of assertion and denial in the field which her sister's voice seemed to cover" (225). Dryfoos himself is heard "snoring" (195) and "snort[ing]" (201). The "fierce, grinding movement of his jaws" (361) is reminiscent of McTeague, and his wife's voice is a "hoarse pipe" (371).

As with McTeague, the Dryfooses' way of speaking combines with other acoustic manifestations of their bodily hexis to put them on the margins of the realm of socially acceptable sound-making. The audiograph Howells furnishes the Dryfoos family with serves to reinforce their social distance from the Marches much the same way Lindau's immigrant speech serves to mark out his deviance from the novel's middle-class norm. In both cases, the physical, audible noises characters make are made to correspond to their political and social position within the novel. From the Marches' middle-class perspective, Lindau's socialist ideas as well as the Dryfooses' vulgar capitalism are the noise that perturbs their own value system.

In various ways, then, the portrayal of figures as different as Lindau, the Dryfooses, McTeague, Schouler, Mr. Sieppe, and Zerkow exernplifies the ways in which authors of the late nineteenth century mark out certain characters as inferior, deviant, or distant on the basis of the sounds their bodies produce. While the processes of inclusion and exclusion enacted by these texts may be based primarily on a character's belonging to a given gender, race, or class--the latter is bome out by 
the fact that McTeague is the only character of purely Anglo-Saxon stock in this group (Dryfoos was "an old Pennsylvania Dutch farmer" [75])-secondary characteristics such as style of dress, intensity of bodily movements, or acoustic profile in important ways form part of the techniques employed in literary texts to represent the legitimate social world. These details of characterization cannot be reduced to an expression or realization of underlying or primary factors of race, class, and gender, and Pierre Bourdieu's concepts of habitus, hexis, and symbolic violence provide us with instruments to discuss the relationship between what, after all, may only appear to be primary and secondary social markers.

This leads to a larger issue in critical debates about realism. Authors of the period often seem obsessed with insignificant details, such as decorations of houses, dresses characters wear, flowers in a garden. Roland Barthes has made the argument that it is primarily this abundance of details with no apparent narrative function which creates verisimilitude in realist texts. ${ }^{35}$ In realist fiction, we find the minutest descriptions of clothes, houses, and furniture that have no other function than to make the narrative more realistic. Roman Jakobson provides an illustrative anecdote for what Barthes would later call l'effet de réel: "A pupil is asked to solve a problem: "A bird flew out of its cage; how soon will it reach the forest if it flies at such and such a speed per minute, and the distance between the cage and the forest is such and such?' 'What color is the cage?' asks the child. This child is a typical realist." ${ }^{.36}$ The technique described by Jakobson and Barthes is used by all writers discussed in this chapter and is probably put to greatest effect in Carrie's unrelenting fascination with the world of commodities. This observation alone should guard us against drawing too rigid a distinction between a realist like Howells on the one hand and a writer like Dreiser, whom Donald Pizer identifies as "the author whose work and career most fulfill the received notion of American naturalism," on the other. ${ }^{37}$

Against Jakobson and Barthes, however, I maintain that many of these details are functional in that they are used by authors to indicate the social status and various personality traits of fictional characters. For instance, the three-paragraph description of the three rooms Drouet rents for Sister Carrie and himself serves to document the improvement of her social status. As Carrie leaves.behind the glum poverty of her sister's working-class household, she also leaves behind its "thin rag carpet" (13) for the "good Brussels carpet" of an apartment that is located in an area "occupied by a middle class who were both respectable and moderately well-to-do" (88). Descriptions of habitats acquire an increasingly important function in Dreiser's novel as Carrie's rise to success is reflected in her choice of a luxurious suite in a hotel that sports an "elegantly carpeted and decorated hall, marbled lobby, and showy waiting room" (453) while Hurstwood, down on his luck, is forced to move to a "cheaper room-thirty-five cents a day" (459) before he finally gasses himself in the room of a hostel described as "a dingy affair, wooden, dusty, hard" (499). Acoustic profiles and audiographs participate in this economy as they signal characters' dis tinction and thus position them with regard to the production, circulation, and exchange of various kinds of capital. They are an integral part of the soundscapes of late nineteenth-century literature and contribute significantly to the processes of containment, exclusion, and symbolic violence enacted within the social space of these texts.

\section{Notes}

I gratefully acknowledge the generous financial support of the Swiss National Science Foundation and the Janggen-Pöhn Foundation, which enabled this essay to be written. I must also express my gratitude to Professor John Carlos Rowe (University of California, Irvine) and Professor Hartwig Isernhagen (University of Basel, Switzerland), without whose equally generous intellectual support the essay would not have taken its present form.

1 Walt Whitman, Preface to Leaves of Grass, in The Heath Anthology of American Literature, Volume 1, $3^{\text {sd }}$ edition, ed. Paul Lauter (Boston and New York: Houghton Mifflin, 1998), 2729, 2731.

2 Philip Jenkins, A History of the United States (London: Macmillan, 1997), 174-75.

${ }^{3}$ William Dean Howells, A Hazard of New Fortunes (London: Meridian, 1995), 158. Hereafter cited parenthetically.

${ }^{4}$ Henry Adams, The Education of Henry Adams, ed. Jean Gooder (London: Penguin, 1995), 229.

${ }^{5}$ Daniel H. Borus, Writing Realism: Howells, James, and Norris in the Mass Market (Chapel Hill: Univ. of North Carolina Press, 1989), 171.

${ }^{6}$ Frank Norris, Mc Teague: A Story of San Francisco (London: Penguin, 1994), 6566. Hereafter cited parenthetically. 
7 Emst Cassirer, The Philosophy of Symbolic Forms, Volume 2: Mythical Thought, trans. Ralph Manheim (New Haven: Yale Univ. Press, 1955), 65. For a sustained discussion of mythical thought in literature, see András Horn's Mythisches Denken und Literatur (Würzburg: Königshausen und Neumann, 1995).

${ }^{8}$ Bruce Smith, The Acoustic World of Early Modern England: Attending to the OFactor (Chicago: Univ. of Chicago Press, 1999), 306.

${ }^{9}$ Theodore Dreiser, Sister Carrie, ed. James L. W. West III and intro. Alfred Kazin (London: Penguin, 1995), 424. Hereafter cited parenthetically.

${ }^{10}$ Smith, The Acoustic World, 322. Smith draws on the work of Vivian Salmon to delineate "the multiple ways in which Native American languages were read in terxas of Irish and Irish in terms of Native Axnerican languages" (325).

"Pierre Bourdieu and Jean-Claude Passeron, Reproduction in Education, Society and Culture, trans. Richard Nice (London: Sage, 1977), 4.

i2 See Bourdieu and Passeron, Reproduction, as well as Bourdieu's highly influential Distinction: A Social Critique of the Judgement of Taste, trans. Richard Nice (London etc.: Routiedge \& Kegan Paul, 1984).

${ }^{13}$ Bourdieu and Passeron, Reproduction, 5.

${ }^{14}$ See also Richard Jenkins's Pierre Bourdieu (London and New York: Routledge, 1992), 105 .

Is Pierre Bourdieu, Language and Symbolic Power, ed. John B. Thompson, trans. Gino Raymond and Matthew Anderson (Cambridge: Harvard Univ. Press, 1991).

${ }^{16}$ Pierre Bourdieu, Outline of a Theory of Practice, trans. Richard Nice (Cambridge: Cambridge Univ. Press, 1993), 178

${ }^{17}$ Bourdieu, Language, 66.

${ }^{13}$ An important theoretical as well as practical feature of these different forms of capital is that they can be converted into one another. Economic capital, for instance, can be invested to acquire cultural capital in the form of educational qualifications, which not only increases one's symbolic capital (prestige) but can also be reconverted into economic capital as they are cashed in on the job market. On different kinds of capital and the and their mutul convetiblity, see Bourdien's Outhe, 179, 183 , and Language, 72 as well as Jenkins's Pierre Bourdieu, 84-91, John B. Thompson's "Editor's Introduction," to Bourdieu's Language, 14-15, and Ritzer's Sociological Theory (New York: McGraw-Hill, 1996), 542-43. Syrabolic violence may involve other forms of capital, cultural or social, as well as the unequal distribution of symbolic capital.

19 George Ritzer explains that the objectivist position is identified by Bourdieu with "Durkheim and his study of social facts ... and the structuralism of Saussure, Lévi"
Strauss, and the structural Marxists" while the subjectivist position includes "Sartre's existentialism, ... Schultz's phenomenology, Blumer's symbolic interactionism, and Garfiakel's ethnomethodology" (Sociological Theory, 536). For a discussion of Bourdieu's attempts to overcome the subjectivism-objectivisxn dichotomy as well as his tendency to privilege the objectivist perspective nevertheless, see Jenkins's Pierr Bourdiet, 90-91 and Thompson's "Editor's Introduction," 11.

${ }^{20}$ Bourdieu, Outline, 72

27 Jenkins, Pierre Bourdieu, 78

${ }^{22}$ See Bourdieu, Outline, 80. Bourdieu's concept of class differs from that of, for instance, Marxist critics in significant ways. As Thompson points out in his "Editor' Introduction," "Bourdieu does not define classes in terms of the ownership or nonownership of means of production... For Bourdieu, classes are sets of agents who occupy similar positions in the social space, and hence possess similar kinds and similar quantities of capital, similar life-chances, similar dispositions, etc." (30).

23 Bourdieu, Language, 37

24 Bourdieu, Language, 69-71.

${ }^{25}$ Rebecca Harding Davis, "Life in the Iron-Mills," in The Heath Anthology of American Literature, Volume 2, $3^{\text {rd }}$ edition, ed. Paul Lauter (Boston: Houghton Mifflin, 1998), 54, 63.

${ }^{26}$ Bourdieu, Distinction, 114

${ }^{27}$ Bourdieu, Outline, 87.

${ }^{28}$ Bourdien, Outline, 87. Bourdieu explicitly treats speech as a forrn of corporeal behavior: "It is no coincidence that bourgeois distinction invests the same intention in its relation to language as it inyests in its relation to the body. The sense of acceptability which orients linguistic practices is inscribed in the most deep-rooted of bodily dispositions: it is the whole body which responds by its posture, but also by its inner reac tions or, more specifically, the articulatory ones, to the tension of the market. Language is a body technique, and specifically linguistic, especially phonetic, competence is a dimension of bodily hexis in which one's whole relation to the social world, and one's whole socially informed relation to the world are expressed" (Language, 86).

${ }^{29}$ Bourdieu, Outline, 93-94. Bruce Smith, who formulates bis insights independently of Bourdieu's work, locates the origin of this social mechanism in the early modern period: "In the course of the sixteenth and seventeenth centuries ... bodily control became an ever more visible index of social hierarchy. Etiquette books like Della Casa's Galateo are quite explicit on the subject. Along with spitting, snorting, and breaking wind, open laughter became a sign of inferior social status . . . latughter is a matter not only of physiology but of politics" (Acoustic World, p. 164),

${ }^{30}$ Stressing the active role of human actors in the construction of soundscapes, Helmut 
Kallmann, Adam P. Woog and Hildegard Westerkamp, in the entry for "World Soundscape Project" in the Encyclopedia of Music in Canada, ed. Helraut Kallmann, Gilles Potvin and Kenneth Wintees, $2^{\text {rd }}$ ed. (Toronto: Univ. of Toronto Press, 1992), 1424-25, define a soundscape as the "acoustic manifestation of 'place,' where the sounds give the inhabitants a 'sense of place' and the place's acoustic quality is shaped by the inhabitants' activities and behariour. The meanings of place and its sounds are created precisely because of this interaction between soundscape and people" (1424). The seminal work on soundscape studies is R. Murray Schafer's The Tuning of the World (New York: Knopf, 1977).

${ }^{31}$ Bourdieu, Distinction, 173.

32 June Howard, Form and History in American Literary Naturalism (Chapel Hill: Univ. of North Carolina Press, 1985), 70-103.

${ }^{33}$ In this context, Howells's choice of Europe as the site of the Dryfooses" "apotheosis" (430) may be read as an inversion of the conventional hierarchy between a cultured Europe and an America which possesses neither history nor culture-a view tured Europe and an Amexica which possesses neither history nor culture-a view
which up to the present day informs many a European's perception of the intellectual and cultural climate in the United States.

${ }^{34}$ The Dryfooses' dialect alone does not warrant their exclusion from Howells's fictional community. If that were the case, the Woodburns' Southern dialect would hold a similar fate in store for them. In the Dryfooses' case, it is a combination of divergent political values, social ideas, and several acoustic indicators (outlined below) that locates them outside the novel's social sphere. There is nothing in the Dryfooses' habitus that appeals to Basil March, the novel's privileged consciousness and arbiter. The Woodburns, on the other hand, distinguish themselves by their refreshingly straightforward moral integrity and their dislike of unrestrained commexcialism-stances which March, who inwardly "object[s] to this economic chance world in which we live" (380), can relate to. The Woodburns' Southern dialect thus hints at their preservation of traditional values cherished by the roiddie-class community to which Madison eventwally gains full access through ber marriage to Fulkerson.

${ }^{35}$ Roland Barthes, "The Reality Effect," in French Literary Theory Today, ed. Tzvetan Todorov (Cambridge: Cambridge Univ. Press, 1982), 11-17.

${ }^{36}$ Roman Jakobson, "On Realism in Art," trans. Karol Magassy, in Language and Literature, ed. Krystyna Pomorska and Stephen Rudy (Cambridge: The Belknap Press of Harvard Univ. Press, 1987), 25.

${ }^{37}$ Donald Pizer, "American Literary Naturalism: The Example of Dreiser," in The Theory and Practice of American Literary Naturalism: Selected Essays and Reviews (Carbondale: Southwestem Ilinois Univ. Press, 1993), 57.

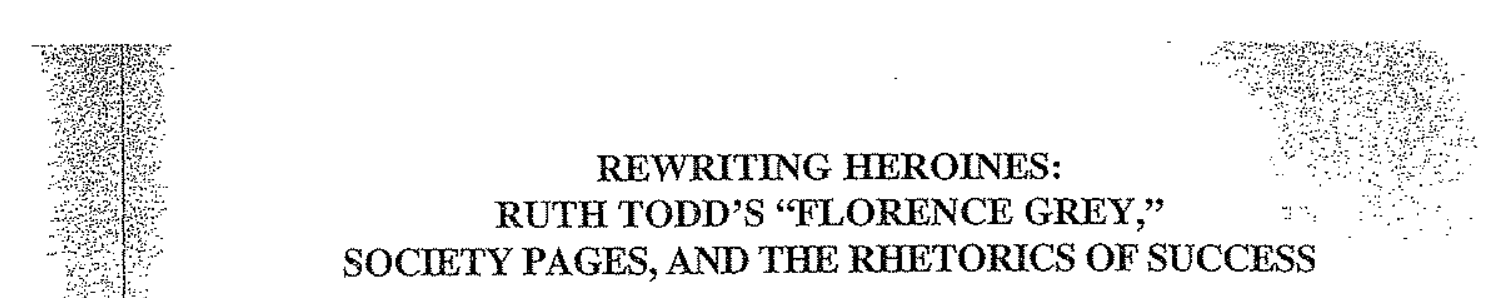

Amy L. Blair

When the beautiful, light-skinned title character of Ruth Todd's "Florence Grey" (1902) is abducted from a garden party at her family's villa, it takes her friends some time to realize her absence is not voluntary. They do not know that the chaste belle of "Negro aristocracy" 1 has rebuffed the less-than-honorable attentions of a wealthy white man, Richard Vanbrugh, who now intends to imprison Florence in a "haunted" mansion and make her his concubine. Eventually the evidence of foul play accretes; Florence's friends and family find a shred of lace from her dress, the roses she cartied, and "the much admired pearl-headed pin she wore in her hair" (185) on the ground. This last object seems to be the key; after its finding, Todd obliquely tells us, "for a while consternation and distraction reigned supreme" (185). We are to assume that Florence's fate has been guessed. But instead of directly narrating the details of police interrogation, search party organization, and the inevitable fainting women that accompany a society belle's abduction, Todd offers her readers only the one vague sentence about generalized "consternation and distraction" and brings her narrative to an abrupt halt with the statement that "what followed can better be described by the insertion of a couple of extracts from the Washington newspapers" (185).

With such a promise, Todd's audience might expect the lengthy newspaper extracts that follow (replete with headlines) to reveal new information about the kidnapping case, or at least about the things not covered in Todd's own narration. But these newspaper extracts disclose only the barest facts about the case, and they are things we already know: Florence was missing, assumed abducted, the search began and an award has been posted. Why, then, should two journalistic accounts of Florence's disappearance-one from a white paper and one from a black paper-interpose to delay the narration of her rescue? One suggestion comes to mind if we back up to the discovery of Florence's absence, looking carefully at the way her friends and family talk about the evidence she has left 